\title{
Haemophagocytic lymphohistiocitosis - a case report in infant
}

\author{
Eliana Toledo \\ From 3rd WAO International Scientific Conference (WISC) 2014 \\ Rio de Janeiro, Brazil. 6-9 December 2014
}

\section{Background}

The purpose of this case report is to alert for a serious disease, potentially lethal, often confused with sepsis, however, it is an auto inflammatory disease, with massive activation of macrophages and consequent tissue destruction.

\section{Methods}

Review of electronic medical record.

\section{Results}

We report a case of an infant, 1 year and 8 months old, male, that was in intensive care unit for five months with initial diagnosis of acute diarrhea, dehydration and hemolytic uremic syndrome.

The infant developed fever, hepatosplenomegaly, cutaneous rash, bicytopenia, elevated serum ferritin, liver enzyme abnormalities, encephalitis, acute renal failure and serum hypogammaglobulinemia.

The diagnosis of hemophagocytic lymphohistiocytosis was suspected and confirmed with biopsy of bone marrow with evidence of hemophagocytosis. Chemotherapy was instituted promptly with etoposide, dexamethasone and intravenous human immunoglobulin (immunomodulation dosis), with a favorable evolution and discharge from the intensive care unit.

\section{Conclusions}

We call attention to the clinical and laboratory diagnosis of hemophagocytic histiocytosis which is a potentially lethal disease if not diagnosed early.

\section{Consent}

Written informed consent was obtained from the patient for publication of this abstract and any accompanying

Faculty of Medicine of São José Do Rio Preto, Brazil images. A copy of the written consent is available for review by the Editor of this journal.

Published: 8 April 2015

doi:10.1186/1939-4551-8-S1-A76

Cite this article as: Toledo: Haemophagocytic lymphohistiocitosis - a case report in infant. World Allergy Organization Journal 2015 8(Suppl 1): A76.
Submit your next manuscript to BioMed Central and take full advantage of:

- Convenient online submission

- Thorough peer review

- No space constraints or color figure charges

- Immediate publication on acceptance

- Inclusion in PubMed, CAS, Scopus and Google Scholar

- Research which is freely available for redistribution

\section{() Biomed Central}

